\title{
The Social Work in the Continuous Care Unit
}

\section{O Serviço Social na Unidade de Cuidados Continuados Integrados}

\author{
Ana Rita dos Santos de Pina Duarte ${ }^{1 *}$ \\ ${ }^{1}$ LNostrum, Residência São Domingos, 2640-232 Encarnação, Mafra \\ Email:anaritaduarte2011@gmail.com
}

* This work was developed as part of the research conducted for the Master Dissertation in Integrated Continuous Care, ECTS - U Lusófona, Lisboa

* Este trabalho faz parte da investigação desenvolvida para obtenção do grau de Mestre em Cuidados Continuados Integrados, ECTS - U Lusófona, Lisboa

\begin{abstract}
The Social Worker is a qualified professional who, by proper training intervention and by research and analysis of social reality, is ready to act, execute and evaluate services, programs and social policies aiming to preserve, protect and expand human rights and social justice.

The Portuguese National Network of Integrated Continuous Care (RNCCI) emerged in 2006 considering the health care needs with the recognition that the system could not cope with the rehabilitation needs of the different groups of patients. Thus, this health structure was created to establish an intermediary between health and social care and as a way to connect hospitalization and clinical discharge, as well as re-integration into the community.

The primary goal was to clearly assess the importance of the social service in one Continuous Care Unit by using, as methodology, questioner applications for different professionals (social service team and other health team members).

The results were helpful and positive, allowing us to conclude that the social service area is valued by the team members at different levels with a fundamental goal of supporting patients, families / caregivers and the other health professionals in their interventions.
\end{abstract}

Keywords: Social Service; Social Worker, Social Intervention, Health and Continuous Care.

\section{Resumo}

O Assistente Social é um profissional qualificado que, privilegiando e usufruindo de uma intervenção de formação, de pesquisa e de análise da realidade social, actua na formulação, execução e avaliação de serviços, programas e políticas sociais que visam a preservação, defesa e ampliação dos direitos humanos e da justiça social.

A Rede Nacional de Cuidados Continuados Integrados (RNCCI) surgiu em 2006 em função das necessidades analisadas no sistema de saúde português e da constatação de que o mesmo não promovia a reabilitação dos diferentes grupos de doentes. Assim, criou-se a Rede pela necessidade de se instituir um nível intermédio e integrado de cuidados de saúde e de apoio social e como meio de ligação entre o internamento hospitalar e o regresso à comunidade.

Metodologicamente, e através da aplicação de questionários numa Unidade de Cuidados Continuados Integrados, objectivou-se evidenciar a importância do Serviço social nessa Unidade, quer através da opinião de profissionais de Serviço social como de profissionais de diferentes áreas.

Os resultados foram produtivos e positivos, concluindo-se que a área do Serviço social é valorizada intervindo a diversos níveis, apoiando os utentes, as famílias / cuidadores e os profissionais das restantes áreas.

Palavras-chave: Serviço social; Assistente social; Intervenção social; Saúde e Cuidados continuados. 


\section{Introdução}

Social service, in its various forms, addresses the multiple and complex relationships that are established between people and their environments. The mission of a Social assistant is to help their client to develop their full potential and to prevent dysfunctions. Thus, social service professionals are active agents of change in society as well as in the individual's lives, families and communities. In this regard, Social service is an interrelated system of values, theories and practice.

The Portuguese National Network of Integrated Continuous Care, created in 2006, improved the clinical and social responses, mostly due to the great need in providing adequate support to patients with chronic diseases and with functional dependency or/and incurable diseases in a terminal situation ${ }^{1}$. Thus, the social service is actually present in all components related with the network, working with many different models and approaches.

The subject delimitation: According to Sousa and Baptista, "An investigation is a process of structuring the knowledge, aiming to conceive or to validate human knowledge." Therefore, it is a learning process not only for the researcher, but also to the society in general (Sousa \& Baptista 2011, p.3). In this sense, the present study, aimed to answer the question "Is the Social Service valued within the Continuous Care Unit?", and takes place at the Continuous Care Unit LNostrum SA, one institution that is part of the Portuguese National Network of Integrated Continuous Care.

The secondary goals included the assessment of:

a) the importance of the social work assistant at the $\mathrm{ICCU}^{2}$ based on the opinions of the other social work members,

b) the importance of the social service based on the opinion of other health professionals working in the same institution .

Justification of the chosen theme: In Portugal, over the years, several health system reforms were registered, all aiming to improve the quality of the health care provided. Based on those sequential changes the Portuguese National Network of Integrated Care

\footnotetext{
1 According to the functional content of the social service area, social assistants are authorized to act autonomously, both in research and in intervention for prevention, mitigation and resolution of social problems and promoting the satisfaction of needs. They are professionals who are placed at local, regional and central levels participating in the design, definition, implementation and evaluation of social policy measures by networking and partnering.
}

\section{Introdução}

O Serviço social, nas suas diversas vertentes, abrange as múltiplas e complexas relações que se estabelecem entre as pessoas e o meio que as envolve. A sua missão é ajudá-las a desenvolverem todas as suas potencialidades, a enriquecerem as suas vidas e a prevenirem as disfunções. Desta forma, os profissionais do Serviço social são agentes de mudança na sociedade e também na vida dos indivíduos, famílias e comunidades a quem o seu trabalho se dirige. Ao Serviço social está subjacente um conjunto articulado de valores, de teorias e de práticas.

Em 2006, com o início da Rede Nacional de Cuidados Continuados Integrados, aumentou-se a resposta de apoio clínico e social, devido à grande necessidade sentida no proporcionar apoio à população com doença crónica, com dependência funcional e doença incurável em situação terminal. Neste contexto, o Serviço social encontra-se presente em todas as instituições e organismos da Rede, intervindo das mais variadas formas, no âmbito do seu conteúdo funcional ${ }^{1}$.

A grande característica desta Rede é o facto das componentes social e saúde se complementarem trabalhando em conjunto, o que constitui um aspecto diferenciador relativamente a outros serviços prestadores de cuidados existentes até sua formação.

Delimitação do assunto: Segundo Sousa e Baptista, "Uma investigação trata-se de um processo de estruturação do conhecimento, tendo como objectivos fundamentais conceber novo conhecimento ou validar algum conhecimento preexistente, ou seja, testar alguma teoria para verificar a sua veracidade. Trata-se, portanto, de um processo de aprendizagem - não só para o indivíduo que a realiza, mas também para a sociedade em geral" (Sousa \& Baptista, 2011, p.3). Assim, e em concordância com os autores, a investigação objectivava dar resposta à questão «Será o Serviço Social valorizado no âmbito da Unidade de Cuidados Continuados Integrados?» e desenvolveu-se na Unidade de Cuidados Continuados Integrados LNostrum SA, que integra a Rede Nacional de Cuidados Continuados Integrados, abrangendo grande parte dos profissionais que aí intervêm.

Este estudo teve como objectivo geral evidenciar a importância do Serviço social na Unidade de Cuidados Continuados Integrados, apoiando-se em dois objectivos específicos:

- Evidenciar a importância do trabalho do Assistente social na $\mathrm{UCCI}^{2}$, baseado em opiniões das profissionais de Serviço social que trabalham na LNostrum SA e,

\footnotetext{
1 Segundo o conteúdo funcional da área do Serviço social, os Assistentes sociais, estão habilitados a intervir autonomamente, tanto em investigação como na intervenção para prevenção, atenuação e resolução de problemas sociais e promoção na satisfação das necessidades. São profissionais que se situam aos níveis local, regional e central participando na concepção, definição, execução e avaliação das medidas de política social, trabalhando em rede e em parceria.
} 
was created by the Law n. ${ }^{\circ} 101 / 2006$, of 6 June $^{3}$ (DL 101/2006), which states that the network was "(...) created (...) within the Ministries of Health and the Labour and Social Solidarity (...)", which by implementation units and teams "(...) financially sustainable (...), supported by public, social and private partnerships (...)", have clearly defined objectives, namely to promote care and social support continuity for all citizens who temporarily or indefinitely, suffer from some degree of dependency and chronic disease, by promoting their autonomy and functionality, providing wellbeing and quality of life.

This research sought to examine the self-opinion from LNostrum SA social assistants and how the others team members perceived their intervention.

\section{Material and Methods}

This work was based on the investigation-action method objectifying " (...) the practice improvement in the various fields of action ( ... ) by changing and learning from the consequences of those changes, while still allowing the participation of all involved " (Sousa \& Baptista 2011 , p.65 )

Since the investigation-action method is a qualitative and participative methodology, it adopts a theoreticalbased-interpretive point of view when focusing on the change-oriented process.

The study involved the use of data collection techniques to prepare a qualitative study. According to Souza \& Baptista "Qualitative research has emerged (...) to analyse and study the behaviour subjectivity in the activities of individuals and organizations. " (Sousa \& Baptista 2011, p.56 ).

The Analysis Field (the Continuous Care Unit, LNostrum SA): LNostrum SA's Mission is " ( ... ) to provide global care to all inpatients aiming to promote and /or to maintain their autonomy and well-being ." The institution as its Vision "( ...) to be a reference of good practice within the Portuguese National Network of Integrated Continuous Care and also with the community. " The LNostrum SA unit is the only unit in the coun-

3 Law No.101/2006, of 6 June, creating the National Network for Integrated Continuous Care in Portugal
- Averiguar a opinião que outros profissionais, que trabalham nessa mesma Unidade e que estão directamente envolvidos no processo de gestão de internamento e intervenção na alta, têm sobre a importância do trabalho do Assistente social na UCCI.

Justificação do tema escolhido: Em Portugal, ao longo dos anos, puderam observar-se reformas continuadas no sistema de saúde que visaram o aperfeiçoamento do próprio sistema. Assim, e com base nesse percurso de alterações, criou-se a Rede Nacional de Cuidados Continuados Integrados pelo Decreto-Lei n. ${ }^{\circ}$ 101/2006, de 6 de Junho ${ }^{3}$ (DL 101/2006), no qual se afirma que a Rede foi " (...) criada (...) no âmbito dos Ministérios da Saúde e do Trabalho e da Solidariedade Social (...)", que, através da implementação de unidades e equipas “(...) financeiramente sustentáveis (...), assentes em parcerias públicas, sociais e privadas (...)", têm objectivos definidos, nomeadamente, o de promover a continuidade dos cuidados de saúde e apoio social a todo o cidadão que sofra, temporária ou indefinidamente, de algum grau de dependência e de doença crónica, promovendo a sua autonomia e aumentando a funcionalidade proporcionando bem estar e qualidade de vida.

A investigação desenvolvida pretendeu analisar a intervenção das Assistentes sociais da LNostrum SA e o quanto essa intervenção é valorizada pelas próprias e pelos profissionais que integram a equipa multidisciplinar.

\section{Material e Métodos}

Este trabalho foi desenvolvido com base no método investigação-acção objectivando "(...) a melhoria da prática nos diversos campos da acção (...) mediante a mudança e a aprendizagem a partir das consequências dessas mudanças, permitindo ainda a participação de todos os implicados." (Sousa \& Baptista, 2011, p.65) A acção sustenta-se numa teoria implícita e o propósito da reflexão crítica é tornar a teoria explícita. Sendo a investigaçãoacção uma metodologia qualitativa e participativa, adopta no processo orientado para a mudança, um ponto de vista interpretativo subjacente a uma explicitação teórica.

O trabalho envolveu a utilização de técnicas de recolha de dados para a preparação de um estudo qualitativo, dado que, a definição do problema de investigação surgiu mediante experiências profissionais da investigadora pois, segundo Sousa e Baptista "A investigação qualitativa surgiu (...) para a análise e estudo da subjectividade inerente ao comportamento e à actividade das pessoas e das organizações." (Sousa \& Baptista, 2011, p.56)

Campo de Análise - Unidade de Cuidados Continuados Integrados, LNostrum SA: A LNostrum SA tem como Missão "(...) a prestação de cuidados implicando cuidados globais aos utentes em regime de internamento, com vista à promoção e/ou manutenção da sua autonomia e bem-estar." e “(...) por Visão, ser uma unidade de internamento de referência para a Rede Nacional de Cuidados Continuados Integra-

3 Decreto-Lei n. ${ }^{\circ} 101 / 2006$, de 6 de Junho, cria a Rede Nacional de Cuidados Continuados Integrados, em Portugal 
try comprising of all four different types of hospitalization, totalling at present, 199 contracted users.

Population and Sample: As stated by Sousa and Baptista, "The accuracy of research results from the entire population would naturally be much higher in comparison to a small representative portion, called sample" (Sousa \& Baptista 2011 , p .72)

The professionals included in this research, corresponded to all professionals working in LNostrum SA directly involved in clinical management and discharge comprised of 60 professionals, specifically, three social workers, eight medical doctors, 36 nurses, two clinical psychologists, one sociocultural animator, one speech and language therapist, two occupational therapists, six physical therapists and one dietician.

All other professionals were excluded due to the fact that they do not attend team meetings with family or make any decisions regarding the patient interventions defined by the patients Individual Intervention Plan (IIP).

From table 1, we noted the Human Resources involved and the interests obtained:

Data Collection Techniques: According to Sousa and Baptista, the techniques of data collection are defined as " $(. .$.$) the set of operating procedures that allows us$ to gather empirical data, a key part of the investigation process." (Sousa \& Baptista 2011, p.70)

Two questionnaires were developed based on the practical experience of the first author.

The first instrument was directed to Social service professionals and the second one, focused on other professionals directly involved in the clinical management and discharge processes. dos e para a comunidade como exemplo de excelência e boa prática." (LNostrum SA)

A LNostrum SA é a única Unidade do país composta pelas quatro tipologias de internamento, totalizando, na actualidade, 199 utentes contratualizados.

População e Amostra: Tal como afirma Sousa e Baptista, "A precisão dos resultados da investigação seria, naturalmente, muito superior se fosse analisada toda a população em vez de uma pequena parcela representativa, denominada amostra." (Sousa \& Baptista, 2011, p.72).

Os profissionais abrangidos na investigação correspondendo à totalidade de profissionais que trabalham na LNostrum SA e que estão directamente envolvidos no processo de gestão de internamento e intervenção na alta, são 60 pessoas e, distribuem-se do seguinte modo, três assistentes sociais, oito médicos, 36 enfermeiros, dois psicólogos clínicos, uma animadora sociocultural, uma terapeuta da fala, duas terapeutas ocupacionais, seis fisioterapeutas e uma dietista. A exclusão das restantes áreas profissionais, deveu-se ao facto dessa população não participar nas reuniões de equipa com a família nem tomar decisões face às intervenções necessárias para 0 utente através do Plano Individual de Intervenção (PII) elaborado pelos profissionais seleccionados para esta investigação. Pela tabela 1, evidenciamos os Recursos Humanos envolvidos e as participações obtidas.

Técnicas de recolha de dados: Segundo Sousa e Baptista, as técnicas de recolha de dados são definidas como sendo "(...) o conjunto de processos operativos que nos permite recolher os dados empíricos que são uma parte fundamental do processo de investigação." (Sousa \& Baptista, 2011, p.70).

Foram elaborados dois questionários baseados na experiência prática da investigadora e no dia-a-dia na LNostrum SA, um direccionado para profissionais de serviço social e outro que tem como população-alvo todos os profissionais que estão directamente envolvidos no processo de gestão do internamento e intervenção na alta.

Table 1 / Tabela 1: Totality of Professional's LNostrum SA and all of those who participated in the study, by professional area.

Totalidade de Profissionais da LNostrum SA e totalidade dos que participaram no estudo, por área profissional.

\begin{tabular}{lcc}
\hline \multicolumn{1}{c}{$\begin{array}{c}\text { Professional area } \\
\text { Área profissional }\end{array}$} & $\begin{array}{c}\text { Sample } \\
\text { Amostra }\end{array}$ & $\begin{array}{c}\text { Participations } \\
\text { Participações }\end{array}$ \\
\hline Social Service / Serviço Social & 3 & 3 \\
\hline Medicine / Medicina & 8 & 4 \\
\hline Nursing / Enfermagem & 36 & 35 \\
\hline Psychology / Psicologia & 2 & 2 \\
\hline Dietetic / Dietética & 1 & 1 \\
\hline $\begin{array}{l}\text { Sociocultural Animation } \\
\text { Animação Sociocultural }\end{array}$ & 1 & 1 \\
\hline $\begin{array}{l}\text { Speech and Language Therapy / } \\
\text { Terapia da Fala }\end{array}$ & 1 & 2 \\
\hline $\begin{array}{l}\text { Occupational Therapy / Terapia } \\
\text { Ocupacional }\end{array}$ & 2 & 6 \\
\hline Physiotherapy / Fisioterapia & 6 & $\mathbf{5 5}$ \\
\hline \multicolumn{1}{c}{ TOTAL: } & $\mathbf{6 0}$ & 1 \\
\hline
\end{tabular}


Questionnaires included questions allusive to the indicators chosen to answer the research questions, namely if "Is the Social Service valued within the Continuous Care Unit? '.

Both surveys included five sheets with questions subdivided into three parts:

I. The characterization of the participant, where they were asked if LNostrum SA was their first employer, their clinical setting and their professional area (this latter is absent in the questionnaire for Social service); II. The characterization of the professional's opinion, based on the cited indicators using a 'Likert' scale, where those directed to the social service professionals contains three different considerations on the' Social Intervention ' indicator;

III. The characterization of the personal opinion regarding limitations of social services, by an open response question.

Section II evidenced by the following illustrative table with regard to the indicator 'Social Intervention':

The results obtained and uncovered in this investigation resulted from the application of two questionnaires (one suited to social work professionals and the second for other selected areas) that encompassed four aspects that we considered essential for research and involving the day-to-day unit in particular, 'Team', 'Social Intervention', 'Discharge' and 'Meeting'.

The quantitative data collected, as exemplifiedby Tabela2
Para os questionários foram produzidas questões que são alusivas aos indicadores escolhidos que, por sua vez e através da informação produzida, irão responder à pergunta de partida deste estudo, nomeadamente, «Será o Serviço Social valorizado no âmbito da Unidade de Cuidados Continuados Integrados?».

Ambos os inquéritos, com cinco folhas de questões, foram subdivididos em três partes:

I. Caracterização do inquirido, onde nos interessou saber se a LNostrum SA foi a primeira entidade empregadora, qual ou quais as tipologias de internamento onde é, maioritariamente, desenvolvida a intervenção e a área profissional (esta última não se encontra no questionário produzido para o Serviço social);

II. Caracterização da opinião do profissional, com base nos indicadores citados e através da Escala tipo «Lickert», sendo que o específico para as profissionais de Serviço social difere no acréscimo de três considerações no indicador «Intervenção Social»;

III. Caracterização da opinião pessoal relativamente às limitações do serviço social, numa pergunta de resposta aberta, enquanto conclusão do questionário.

Evidenciamos a secção II através da seguinte tabela exemplificativa no que respeita ao indicador «Intervenção Social»: Os resultados obtidos e expostos nesta investigação resultaram da aplicação de dois questionários (um adequado às profissionais de serviço social e o segundo para as restantes áreas seleccionadas) que englobavam quatro aspectos que considerámos essenciais para a investigação e que envolvem o dia-a-dia da Unidade, nomeadamente, «Equipa», «Intervenção Social», «Alta» e «Reunião».

Os dados quantitativos recolhidos, conforme respostas

Table 2/ Tabela 2 - Example from the 'Social Intervention' table as a section of the questionnaire used in the study (S.D.: Strongly Disagree; A.: Agree; N.: Neutral; D.: Disagree; S.A.: Strongly Agree). Exemplo da tabela «Intervenção Social» enquanto secção do questionário aplicado no âmbito deste estudo (D.T.: Discordo totalmente; C. Concordo; I: Indiferente; D.P.: Discordo parcialmente; C.T.: Concordo totalmente)

\begin{tabular}{l|r|r|r|r|r}
\hline \multicolumn{1}{|c|}{ Questions / Questões } & $\begin{array}{c}\text { S.D. } \\
\text { D.T. }\end{array}$ & $\begin{array}{c}\text { A. } \\
\text { C. }\end{array}$ & $\begin{array}{c}\text { N. } \\
\text { I. }\end{array}$ & $\begin{array}{c}\text { D. } \\
\text { D.P. }\end{array}$ & $\begin{array}{c}\text { S.A. } \\
\text { C.T. }\end{array}$ \\
\hline $\begin{array}{l}\text { 2.1. I consider the work of the Social Service too bureaucratic. } \\
\text { 2.1. Considero o trabalho do Serviço Social demasiado burocrático }\end{array}$ & & 13 & 13 & 24 & 2 \\
\hline
\end{tabular}


replies, were worked through the software SPSS - Statistical Package for Social Sciences for Windows.

\section{Results}

Considering the proposed objectives for this study, two major evidences resulted:

- Social work professionals consider their position within the unit to be very important, considering that they intervene on patients / families / caregivers but also with the remaining team. They are considered to assume organizational responsibilities such as scheduling meetings, attention and follow-up discharge responsibility, and planning of Individual Intervention Plans (IIP), among others. Although professionally fulfilled, the Social workers considered themselves poorly recognized regarding their salary and their professional responsibilities.

- Considering the other health professionals, we concluded that they value the Social service in LNostrum SA and are in agreement with the level of responsibilities assumed by the social service professionals, both regarding users / families / caregivers and colleagues. exemplificadas através da Tabela 2, foram trabalhados através do programa informático SPSS - "Statistical Package for Social Science", para o Windows.

\section{Resultados}

Tendo em consideração os objectivos propostos para este estudo, ressaltaram duas grandes evidências:

- As Assistentes Sociais dão importância à sua área na Unidade, considerando que intervêm tanto para os utentes/famílias/cuidadores como para a restante equipa, trabalhando e estando responsáveis por questões organizacionais, como o agendamento de reuniões, a atenção e responsabilidade face à alta dos indivíduos internados, a organização e planeamento dos Planos Individuais de Intervenção (PII), entre outras. Inclusivamente consideram-se profissionais realizadas, mas salarialmente mal reconhecidas, também pelas responsabilidades que têm;

- No que respeita aos profissionais das restantes áreas, concluímos que valorizam a existência do Serviço social na LNostrum SA e as responsabilidades que as profissionais de Serviço social têm, tanto em relação aos utentes/famílias/cuidadores como em relação aos colegas.

Table 3 / Tabela 3 - Questions and answers from questionnaires applied to Social Workers. (S.D.: Strongly Disagree; A.: Agree; N.: Neutral; D.: Disagree; S.A.: Strongly Agree).

Questões e respostas dos questionários realizados às Assistentes Sociais ( D.T.: Discordo totalmente; C. Concordo; I: Indiferente; D.P.: Discordo parcialmente; C.T.: Concordo totalmente)

\begin{tabular}{|c|c|c|c|c|c|}
\hline Questions / Questões & $\begin{array}{l}\text { S.D. } \\
\text { D.T. }\end{array}$ & $\begin{array}{l}\text { A. } \\
\text { C. }\end{array}$ & $\begin{array}{c}\text { N. } \\
\text { I. }\end{array}$ & \begin{tabular}{c|} 
D. \\
D.P.
\end{tabular} & $\begin{array}{l}\text { S.A. } \\
\text { C.T. }\end{array}$ \\
\hline $\begin{array}{l}\text { 1.4. My intervention is intimately linked to teamwork. } \\
\text { 1.4. A minha intervenção está intimamente ligada ao trabalho em } \\
\text { equipa. }\end{array}$ & & & & 1 & 2 \\
\hline $\begin{array}{l}\text { 1.9. The other professionals often ask me to collect information on } \\
\text { patients and families / caretakers. } \\
\text { 1.9. Os restantes profissionais, muitas vezes, procuram-me para } \\
\text { recolherem informações relativas aos utentes e famílias/cuidadores. }\end{array}$ & & & & & 3 \\
\hline $\begin{array}{l}\text { 1.11. The Social Services are responsible for scheduling and organizing } \\
\text { the Individual Intervention Plans (IIP). } \\
\text { 1.11. É o Serviço Social quem está responsável pelo agendamento e } \\
\text { organização dos Planos Individuais de Intervenção (PII). }\end{array}$ & & & & 1 & 2 \\
\hline $\begin{array}{l}\text { 2.5. I believe that the resolution of social problems is as important as } \\
\text { the improvement of any clinical problems. } \\
\text { 2.5. Considero que a resolução dos problemas sociais é tão importante } \\
\text { como a melhoria dos problemas clínicos. }\end{array}$ & & & 1 & 2 & \\
\hline $\begin{array}{l}\text { 2.9. Families / caretakers consider as important the existence of the } \\
\text { Social Service Unit } \\
\text { 2.9. As famílias/cuidadores consideram importante a existência de } \\
\text { Serviço Social na Unidade }\end{array}$ & & & & 2 & 1 \\
\hline $\begin{array}{l}\text { 2.21. I feel professionally fulfilled } \\
\text { 2.21. Sinto-me uma profissional realizada. }\end{array}$ & & & & 3 & \\
\hline $\begin{array}{l}\text { 2.22. My salary does not compensate my responsibilities. } \\
\text { 2.22. A minha remuneração não compensa as responsabilidades que } \\
\text { tenho. }\end{array}$ & & & 1 & & 2 \\
\hline
\end{tabular}


Table 4 / Tabela 4 - Questions and answers drawn from the questionnaires made to other professionals involved in the study.

Questões e respostas retiradas dos questionários realizados aos restantes profissionais

envolvidos no estudo.

\begin{tabular}{|c|c|c|c|c|c|}
\hline Questions / Questões & $\begin{array}{l}\text { S.D. } \\
\text { D.T. }\end{array}$ & \begin{tabular}{|l|} 
A. \\
C. \\
\end{tabular} & \begin{tabular}{c|} 
N. \\
I.
\end{tabular} & $\begin{array}{c}\text { D. } \\
\text { D.P. }\end{array}$ & $\begin{array}{l}\text { S.A. } \\
\text { C.T. }\end{array}$ \\
\hline $\begin{array}{l}\text { 1.6. The Social Service is the intermediate area between the user / } \\
\text { family / caretaker and the team. } \\
\text { 1.6. O Serviço Social é a área intermediária entre o } \\
\text { utente/família/cuidador e a equipa. }\end{array}$ & & 5 & 4 & 30 & 13 \\
\hline $\begin{array}{l}\text { 2.8. Users consider important the presence of the Social Assistant, as } \\
\text { a professional area, in the Unit. } \\
\text { 2.8. Os utentes consideram importante a presença da Assistente } \\
\text { Social, enquanto área profissional, na Unidade. }\end{array}$ & & & 3 & 18 & 31 \\
\hline $\begin{array}{l}\text { 2.10. Families often seek Social Services to transmit their concerns. } \\
\text { 2.10. As famílias muitas vezes procuram o Serviço Social para } \\
\text { transmitirem as suas preocupações. }\end{array}$ & & 3 & 7 & 25 & 17 \\
\hline $\begin{array}{l}\text { 2.18. The social assistant is the professional interacting with the } \\
\text { hospitals and health centers when the individual users do not carry } \\
\text { appropriate documentation on admission. } \\
\text { 2.18. É a Assistente Social, enquanto profissional, quem articula com } \\
\text { os hospitais e centros de saúde quando os utentes isolados não trazem } \\
\text { espólio e documentação aquando da admissão. }\end{array}$ & 1 & 1 & 5 & 21 & 24 \\
\hline $\begin{array}{l}\text { 3.18. I believe that without the Social Service, clinical discharge } \\
\text { would not happen in time. } \\
\text { 3.18. Considero que se não existisse Serviço Social muitas das altas } \\
\text { não ocorriam no tempo previsto. }\end{array}$ & & 5 & 7 & 21 & 19 \\
\hline $\begin{array}{l}\text { 4.3. The team values the fact that the Social Service schedules and } \\
\text { organizes meetings between the staff and the user / family. } \\
\text { 4.3. A equipa valoriza o facto do Serviço Social agendar e organizar } \\
\text { as reuniões entre equipa e utente/família. }\end{array}$ & & 1 & 4 & 20 & 27 \\
\hline $\begin{array}{l}\text { 4.11. It's rare that a team meeting with the family / patient occurs } \\
\text { without the presence of the Social Service professionals. } \\
\text { 4.11. É raro ocorrer uma reunão de equipa com a família/utente sem } \\
\text { a presença da profissional de Serviço Social. }\end{array}$ & 2 & 2 & 2 & 15 & 31 \\
\hline
\end{tabular}

In Tables 3 and 4 are some compelling results of questionnaires made to social workers and other professionals, respectively, and where we can draw some conclusions from this study:

\section{Discussion and Conclusion}

We considered that one of the problems compromising continuity of the social service intervention, is the lack of existing social responses in the community and/or the lack of resources provided to support individuals and respective families / caregivers with adequate dignity and support when clinical discharge takes place.

With the continuous opening of new units across the country, this investigation is far from ending. In this context, different questions can be raised:

First does ICCU solve, by itself, the health quality problem? Regarding Palliative Care Units, for example, will they solve the questions by preventing individuals
Nas tabelas 3 e 4 encontram-se alguns resultados preponderantes dos questionários às Assistentes sociais e aos restantes profissionais, respectivamente, e de onde conseguimos retirar algumas das conclusões para este estudo:

\section{Discussão e Conclusão}

Considerámos que um dos problemas à continuidade da intervenção do Serviço social, é a falta de respostas sociais existentes na comunidade ou a falta de recursos que as mesmas indicam ter para apoiarem condignamente os indivíduos e suas famílias/cuidadores, aquando da alta da Unidade.

Actualmente continua-se a ouvir falar em abertura de mais Unidades pelo país, e concluímos a investigação deixando para discussão os seguintes pontos:

Será que as UCCI por si só resolvem o problema da qualidade em saúde? Poderão resolver, por exemplo, no que respeita aos Cuidados Paliativos, evitando que os 
to spend their end of life in emergency services or in pain at home?

How to provide continuity of care and support if there are no vacancies to caregivers supported by Social Security?

How to avoid social isolation and loneliness if day centres have no adapted transport to individuals in wheelchairs, making this type of social response very difficult and forcing the home enclosure of the elderly?

How to provide the necessary care at home if home support services don't have adequate human resources to provide daily support and /or more than once a day? Shouldn't the Long Lasting and Maintenance typology, that is the current hospitalization to where users are transferred due to a lack of social response in the community, even if they are totally independent, solely accept patients whose clinical situation cannot be supported in households, because there is a $24 \mathrm{~h}$ need for health professional's surveillance? We know that this new legislation addresses the lack of vacancies in Convalescence Units and Medium Length and Rehabilitation Units, previously occupied by those social cases precluding the recovery of users in need. This aspect collides with the previous postulate regarding the Long Lasting typology criteria.

Why not promote social responses that can support users discharged from the Units?

If the RNCCI was created to support users and families / caregivers and also hospitals, in the management of job positions, we actually observe, in the Social service, there are no longer adequate answers supporting the Portuguese National Network of Integrated Care, which is increasingly stagnant.

All these questions serve as topics for further research but also for the community, investors, entrepreneurs and government entities to perceive the reality experienced in RNCCI Units, meaning that this network requires changes accompanying social and economic evolution in the country.

\section{Acknowledgments}

I would like to thank the Continuous Care Unit, LNostrum SA, the institution where the study was conducted and to Professor Dr. Ana Cristina Ribeiro Rama and Master Ana Maria Celeste Bernardo dos Santos for their time and guidance given to this project achievement and its publication. indivíduos passem a sua fase final de vida internados nos hospitais ou em sofrimento no domicílio.

Como proporcionar continuidade de cuidados e apoios se não há vagas em Residências comparticipadas pela Segurança social?

Como evitar o isolamento social e a solidão se os centros de dia não têm transporte adaptado a indivíduos em cadeira de rodas, impossibilitando esse tipo de resposta social promovendo a permanência do idoso no domicílio?

Como prestar os cuidados necessários no domicílio se os Serviços de Apoio Domiciliário não têm recursos humanos para se deslocarem aos domicílios todos os dias da semana e/ou mais do que uma vez por dia?

A tipologia de Longa Duração e Manutenção, actual internamento para onde são transferidos os utentes com falta de resposta social na comunidade, mesmo que sejam totalmente independentes, não deveria acolher, apenas, os doentes cuja situação clínica não possa ser apoiada em residências, pela necessidade de vigilância $24 \mathrm{~h}$ de profissionais de saúde? Sabemos que esta nova normativa resolve a falta de vagas em Unidades de Convalescença e em Unidades de Média Duração e Reabilitação, anteriormente ocupadas pelos casos sociais impossibilitando a recuperação de utentes necessitados mas este aspecto vai contra o postulado em relação à tipologia de Longa Duração.

Porque não promover a abertura de respostas sociais que possam apoiar os utentes que têm alta das Unidades?

Se a RNCCI veio apoiar os utentes e famílias/cuidadores assim como os hospitais na gestão de vagas, actualmente, no Serviço social, denota-se que já não há respostas que apoiem a Rede, estando esta, cada vez mais, estagnada.

Todas estas perguntas tanto servem como temas para novas investigações como para a comunidade, investidores, empreendedores e entidades governamentais se aperceberem da realidade vivida nas Unidades da RNCCI e que esta Rede necessita de alterações que acompanhem as mudanças sociais e económicas do país.

\section{Agradecimentos}

Gostaria de agradecer à Unidade de Cuidados Continuados, LNostrum SA, instituição onde o estudo foi realizado e à Professora Dr. Ana Cristina Ribeiro Master Rama e à Mestre Ana Maria Celeste Bernardo dos Santos pelo tempo e apoio dado para a realização deste projecto e sua publicação. 


\section{Conflict of Interests}

The authors declare that there are no financial and personal relationships that could be viewed as a potential conflict of interest.

\section{Conflito de interesses}

Os autores declaram que não existiam relações financeiras ou pessoais que pudessem ser entendidas como potenciais conflitos de interesse. 


\section{References/ Referências}

1. Sousa, M. ' J. \& Baptista, C. S. (2011). Como fazer Investigação, Dissertações, Teses e Relatórios. Lisboa: Pactor;

2. Decreto-Lei n. ${ }^{\circ} 101 / 2006$ de 6 de Junho. Rede Nacional de Cuidados Continuados Integrados (RNCCI);

3. Duchamp, M. (1989). Especificidades da investigação no trabalho social., La recherche en travail social, Paris: Centurion;

4. LNostrum SA. [LNostrum SA]. http://www. lnostrum.pt/portal/ em www.lnostrum.pt. 